\title{
20. TEMPORAL MAGMATIC EVOLUTION OF THE AOBA BASIN, CENTRAL NEW HEBRIDES ISLAND ARC: PB, SR, AND ND ISOTOPIC EVIDENCE FOR THE COEXISTENCE OF TWO MANTLE COMPONENTS BENEATH THE ARC ${ }^{1}$
}

\author{
L. Briqueu, ${ }^{2}$ C. Laporte, ${ }^{2}$ A. J. Crawford,${ }^{3}$ T. Hasenaka, ${ }^{4}$ P.E. Baker,${ }^{5}$ and M. Coltorti ${ }^{6}$
}

\begin{abstract}
A suite of volcanic and volcaniclastic rocks selected from Ocean Drilling Program Leg 134 Sites 832 and 833 in the North Aoba Basin (Central New Hebrides Island $\mathrm{Arc}$ ) has been analyzed for $\mathrm{Sr}, \mathrm{Nd}$, and $\mathrm{Pb}$ isotopes to investigate the temporal evolution of the arc magmatism. This arc shows two unusual features with respect to other western Pacific arcs: 1) subduction is eastdirected; and 2) a major submarine ridge, the d'Entrecasteaux Zone, has been colliding almost perpendicularly with the central part of the arc since about $3 \mathrm{Ma}$. Volcanic rocks from the upper parts of both holes, generated during the last $2 \mathrm{~m}$.y., show higher ${ }^{87} \mathrm{Sr} /{ }^{86} \mathrm{Sr}$ and significantly lower ${ }^{206} \mathrm{~Pb} /{ }^{204} \mathrm{~Pb}$ and ${ }^{143} \mathrm{Nd} /{ }^{144} \mathrm{Nd}$ values compared to those volcanics erupted before the collision of this ridge, as represented by samples from the lower section of both holes, or remote from the collisional region, in the southern part of the arc. These isotopic differences in the respective mantle sources cannot be interpreted in terms of geochemical input into the mantle wedge induced by the collision itself. Rather, they require long term ( $>500 \mathrm{~m} . \mathrm{y}$.) enrichment processes. The enriched mantle source could be, on a regional scale, a DUPAL-type reservoir with strong similarities to the source of Indian Ocean basalts. Isotopic analyses of drilled rocks from the DEZ show that the anomalous, enriched mantle component is not derived from this feature. We currently cannot identify a source for this enriched component, but note that it also exists in Lau Basin backarc volcanics, lavas from the West Philippine Sea, and also some lavas from the Mariana-Izu-Bonin arc.
\end{abstract}

\section{INTRODUCTION}

The New Hebrides-Solomon Islands arcs are the only arcs in the western Pacific in which subduction is east-dipping. This peculiarity is thought to be due to a reversal of subduction polarity in late Miocene around $10 \mathrm{Ma}$, following collision of the thick Ontong Java Plateau with the northern end of the long Vitiaz Arc (Falvey, 1975; Barsdell et al., 1982; Auzende et al., 1988). It is reasonable to expect that significant changes in the magmatic evolution of this region should be associated with this reversal of polarity. For example, new, eastward-directed subduction may induce magma generation from a mantle wedge that has been previously enriched by the earlier, opposite-dipping subduction regime (Barsdell et al., 1982). Furthermore, since approximately $2 \mathrm{Ma}$, the central section of New Hebrides Island Arc (NHIA) has been in collision with a major submarine bathymetric ridge, the d'Entrecasteaux Zone, which may have commenced collision further south (around $17^{\circ} \mathrm{S}$ ) and is sweeping northward along the trench at about $3.2-4 \mathrm{~cm} / \mathrm{yr}$ (Taylor et al., this volume). Has this collision had a major effect on magmatism in the adjacent arc? This setting provides an opportunity to demonstrate strong links between the tectonic development of an intra-oceanic arc and the nature and isotopic composition of arc magmas generated.

In the NHIA, volcaniclastic sediments and interbedded volcanics and sills in the $3000 \mathrm{~m}$-deep, thickly sedimented North Aoba Basin drilled at Ocean Drilling Program (ODP) Sites 832 and 833 record at

${ }^{1}$ Greene, H.G., Collot, J.-Y., Stokking, L.B., et al., 1994. Proc. ODP, Sci. Results 134: College Station, TX (Ocean Drilling Program).

${ }^{2}$ Laboratoire de Géochemie Isotopique, URA 1371 du CNRS, Département des Sciences de la Terre, Université Montpellier II, 34095 Montpellier Cedex 05, France.

${ }^{3}$ Department of Geology, University of Tasmania, GPO Box 252C, Hobart, Tasmania 7001, Australia.

${ }^{4}$ Department of Petrology and Mineralogy, Faculty of Science, Tokohu University, Aoba, Sendai Miyagi 980, Japan. dom.

${ }^{5}$ Department of Earth Sciences, University of Leeds, Leeds LS2 9JT, United King-

${ }^{6}$ Istituto di Mineralogia, Universita degli Studi di Ferrara, C.so Ercole I ${ }^{\circ}$ d'Este 32, 44100 Ferrara, Italy. least the latter stages ( 10 m.y.) of magmatic evolution of this arc (Fig. 1). This basin is in part related to, and lies immediately east of, the present site of collision of the d'Entrecasteaux Zone (DEZ) (Collot et al., 1985; Falvey and Greene, 1988; Collot, Greene, Stokking, et al., 1992). The DEZ is a major, two-spined submarine ridge that is colliding almost perpendicularly with the central part of the NHIA, pushing up the Western Belt islands of Espiritu Santo and Malakula, with the North and South Aoba basins forming as a flexural downwarp behind these islands (Chung and Kanamori, 1978). Seismic reflection studies (Fisher et al., this volume) have demonstrated a uniform stratification in the North Aoba Basin. Detailed petrologicalgeochemical (Hasenaka et al., this volume) and isotopic studies of extensive lavas, tephras and sills in the upper crustal section of the North Aoba Basin should allow precise documentation of arc magmatism in this region.

It has already been established that a compositional transition exists in modern NHIA arc lavas from the central to the southern part of the arc (Gorton, 1974, 1977; Roca, 1978; Briqueu, 1985; Javoy et al., 1986; Eggins, 1989). In the southern segment of the arc, away from the influence of the DEZ collision, the arc lavas are essentially low- to medium-K basalts and andesites (Marcelot, Dupuy, et al., 1983; Marcelot, Maury, and Lefèvre, 1983; Dupuy et al., 1982). In contrast, the central part of the arc, influenced by the DEZ collision, contains dominantly medium- to high- $\mathrm{K}$ lavas, many transitional between tholeiitic and alkaline compositions (Briqueu et al., 1984; Girod et al., 1979; Eggins, 1993). This geochemical transition can be precisely mapped by $\mathrm{Sr}$ isotope compositions (Briqueu, 1985; Javoy et al., 1986; Peate et al., 1991) (Fig. 2). All arc volcanoes from Santa Maria to Efate show significantly higher $\mathrm{Sr}$ isotope ratios $(0.7036-$ 0.7043 ) than those of volcanoes on the southern islands of Erromango, Tanna, Anatom, and Futuna (0.7030-0.7032). In this paper, we aim to test whether samples from the deep ODP Sites 832 and 833 in the North Aoba Basin record the hypothetical reversal of subduction polarity in this region, and to investigate how the collision of the DEZ affected the isotopic compositions of arc magmas in the central part of the NHIA. 


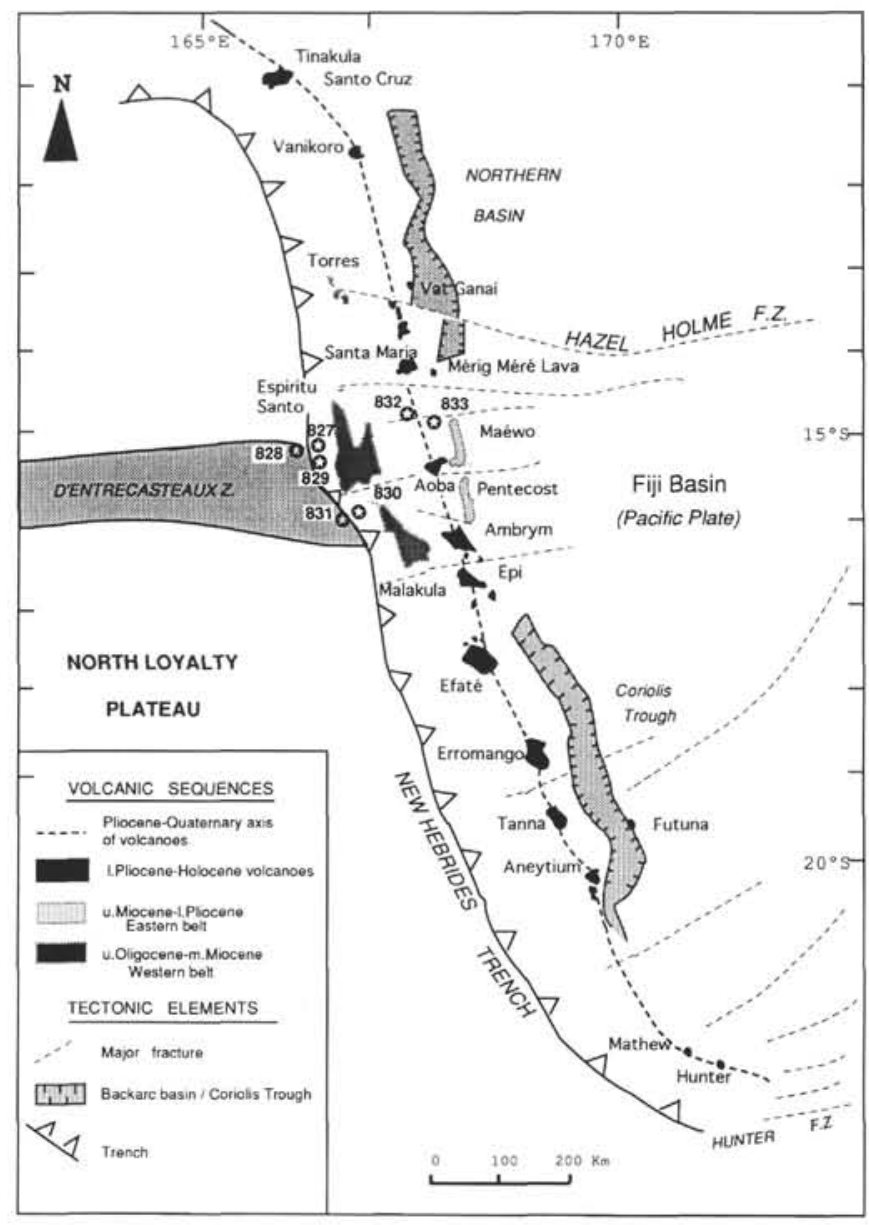

Figure 1. Simplified structural map of the New Hebrides Island Arc showing locations of ODP Sites 832 and 833 (open stars in filled circles).

\section{ANALYTICAL TECHNIQUES}

\section{Sample Preparation}

Samples were washed ultrasonically using alternatively distilled water and acetone until both liquids were clear. After drying, samples were coarsely crushed, and then finely ground in a tungsten carbide mortar. To minimize the effects of seawater alteration before dissolution, powders were leached using $2 \mathrm{~N} \mathrm{HF}+0.5 \mathrm{~N} \mathrm{HBr}$ mixture for 15 $\min$ in an ultrasonic bath, then again with cold $2.5 \mathrm{~N} \mathrm{HCl}$ for another $15 \mathrm{~min}$. These strong leaching experiments result in 55\%-65\% sample weight reduction.

\section{Procedure for $\mathbf{P b}$}

For $\mathrm{Pb}$ isotope measurements $1 \mathrm{~g}$ of sample was dissolved in a $13 \mathrm{~N}$ $\mathrm{HF}+9 \mathrm{~N} \mathrm{HBr}$ solution in a Teflon beaker and warmed on a hot plate for several days. $\mathrm{Pb}$ was separated following the anionic exchange micro-procedure of Manhès et al. (1978). First $\mathrm{Pb}$ is separated from other elements on a column filled with $35 \mu \mathrm{L}$ of resin using $0.5 \mathrm{~N} \mathrm{HBr}$ as an eluant. After $\mathrm{Pb}$ elution with $6 \mathrm{~N} \mathrm{HCl}$ and evaporation to dryness, the residue is purified on a small column filled with $10 \mu \mathrm{L}$ of resin, still in a $0.5 \mathrm{~N} \mathrm{HBr}$ medium. $\mathrm{Pb}$ was analyzed via the silica gel $\mathrm{H}_{3} \mathrm{PO}_{4}$ method using a single Re filament.

\section{Procedure for $\mathrm{Sr}$}

The chemical procedure for $\mathrm{Sr}$ is similar to that reported by Birck and Allegre (1978). Dissolution of $50 \mathrm{mg}$ of sample is carried out with
NEW HEBRIDES ISLAND ARC

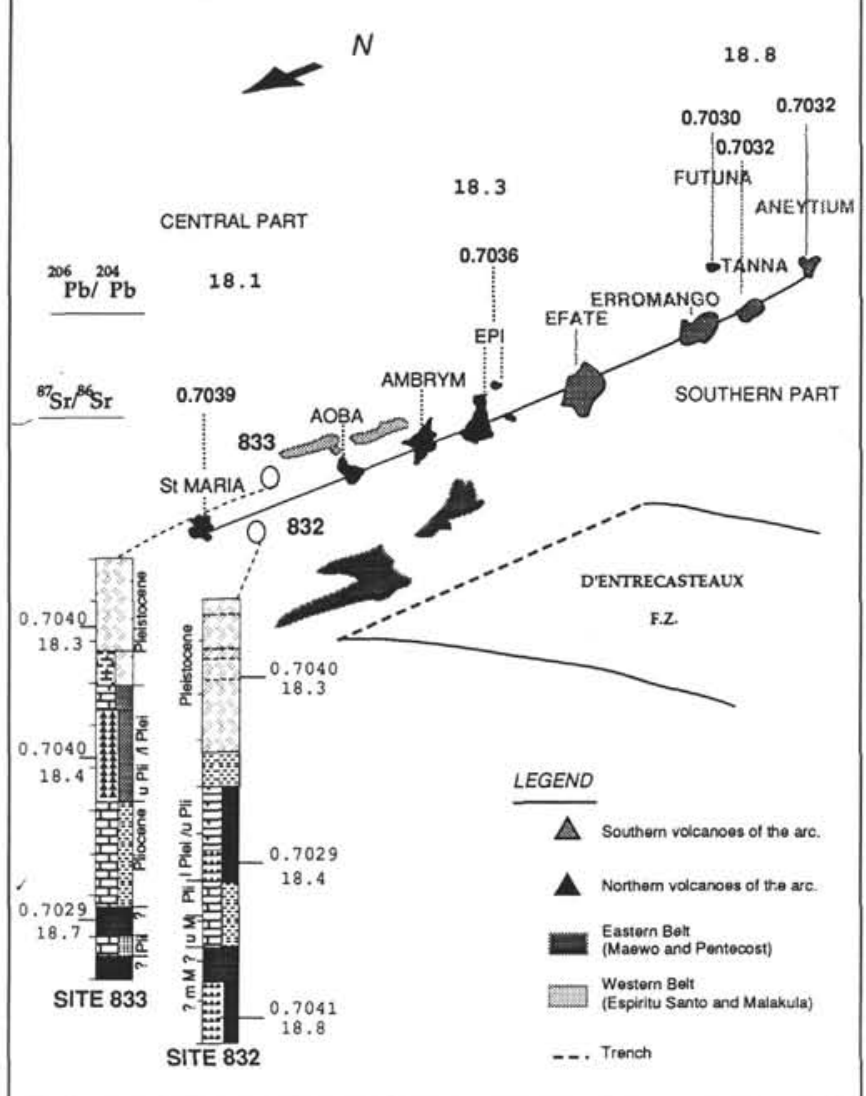

Figure 2. Schematic illustration of the New Hebrides arc showing regional and temporal variations of ${ }^{206} \mathrm{~Pb} /{ }^{204} \mathrm{~Pb}$ and ${ }^{87} \mathrm{Sr} /{ }^{86} \mathrm{Sr}$ values. The volcanoes of the central part of the arc from Santa Maria to Erromango islands located in front of the d'Entrecasteaux collision zone show lower ${ }^{206} \mathrm{~Pb} /{ }^{204} \mathrm{~Pb}$ and higher ${ }^{87} \mathrm{Sr} /{ }^{86} \mathrm{Sr}$ isotopic compositions than volcanoes in the southern part of the arc, far from the collision zone. The pre- and postcollision magmatism, located respectively at the bottom and the top of Holes $832 \mathrm{~B}$ and $833 \mathrm{~B}$, shows this same variation in isotopic ratios.

a $\mathrm{HF}-\mathrm{HNO}_{3}$ mixture. After evaporation to dryness and treatment of the residue with $6 \mathrm{~N} \mathrm{HCl}$, separation of $\mathrm{Sr}$ is carried out on a column filled with AG50-X12, 200-400 mesh cationic resin using $4 \mathrm{~N}$ and $1.5 \mathrm{~N} \mathrm{HCl}$ and then ammonium citrate as eluants. One hundred $\mathrm{ng}$ aliquots of $\mathrm{Sr}$ were loaded onto a W filament previously covered by a Ta activator.

\section{Procedure for Nd}

The analytical method for Nd is similar to those reported by Nakamura (1974) and Richard et al. (1976). The $200 \mathrm{mg}$ samples were dissolved in a $\mathrm{HF}-\mathrm{HNO}_{3}-\mathrm{HClO}_{4}$ mixture, then evaporated to dryness and treated with $6 \mathrm{~N} \mathrm{HCl}$. The major elements were eluted first, using $2 \mathrm{~N} \mathrm{HCl}$ and $4 \mathrm{~N} \mathrm{HCl}$ as eluants, the rare earth elements (REE) follow using $6 \mathrm{~N} \mathrm{HCl}$. The REE were then loaded on to a Teflon column coated with a mixture of the organic acid HDEHP and Teflon powder as support, with $0.25 \mathrm{~N} \mathrm{HCl}$ as eluant to separate $\mathrm{Nd}$ from $\mathrm{Ba}$ and other REE, especially $\mathrm{Sm}$. Nd was loaded on a Ta filament as a phosphate and then measured as $\mathrm{Nd}^{2+}$ metal by a triple filament mode ( $\mathrm{Re}$ in the center for the ionization, and Ta side filaments for the evaporation).

Total system blanks were found to be less than $70 \mathrm{pg}, 20 \mathrm{pg}$, and $80 \mathrm{pg}$ for $\mathrm{Sr}, \mathrm{Nd}$, and $\mathrm{Pb}$, respectively; blanks are in all cases insignificant. All isotopic data were measured on a five multi-collector 


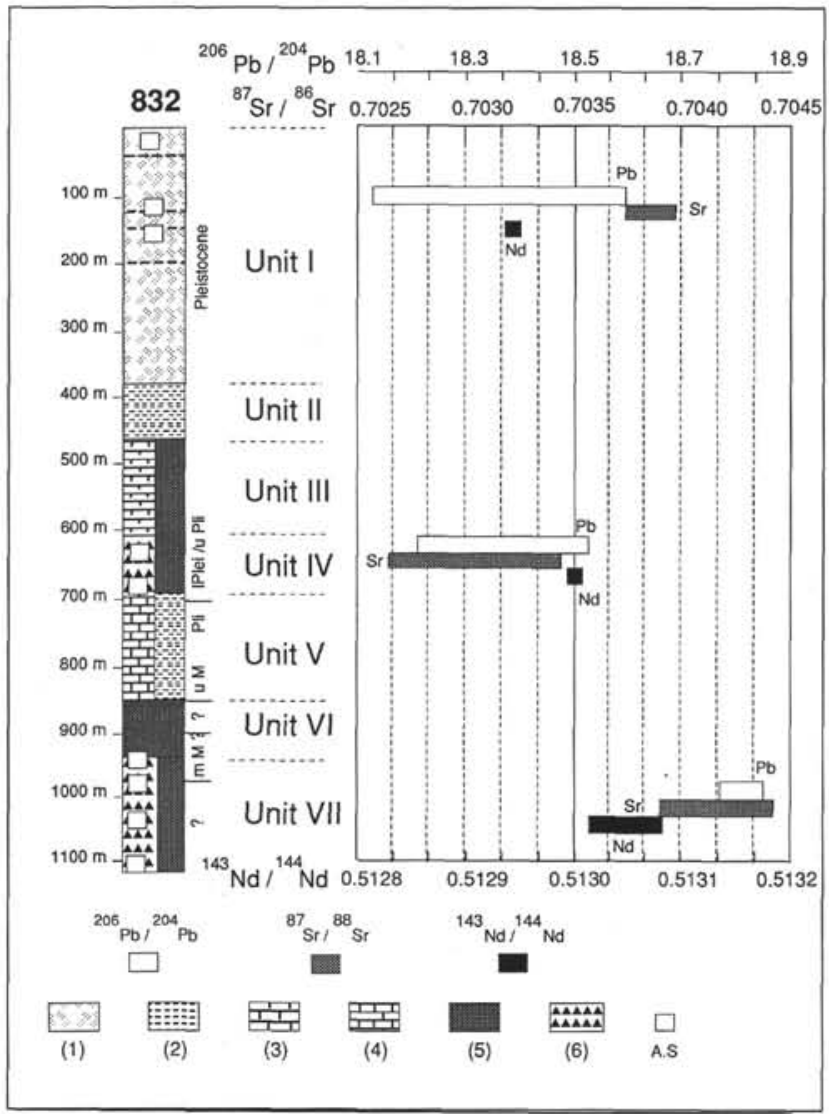

Figure 3. Simplified lithostratigraphic columns and $\mathrm{Pb}, \mathrm{Sr}$, and $\mathrm{Nd}$ isotopic variations of the volcanic and volcaniclastic rocks of Site 832. Key to legend: 1. Volcanic silt/siltstone. 2. Volcanic sandstone-siltstone-claystone. 3. Foraminiferal chalk. 4. Calcareous chalk. 5. Volcanic sand and sandstone. 6. Volcanic breccia. Open squares show levels from which samples were collected for isotopic analysis.

automatic VG Sector mass spectrometer; $\mathrm{Sr}$ and $\mathrm{Nd}$ were run in dynamic mode and $\mathrm{Pb}$ in static mode.

\section{RESULTS}

\section{Regional Tectonic Considerations}

For Site 832 we have sampled lithostratigraphic Unit I ashes, breccias from Unit IV, and the basal calc-alkaline clasts in lithostratigraphic Unit VII. For Site 833 we sampled ashes from Units I and II, lava clasts from the volcanic breccia constituting Unit III, and sills from Unit V. All have arc magmatic affinities and have been analyzed for $\mathrm{Sr}-\mathrm{Nd}-\mathrm{Pb}$ isotopes. Sample locations in the drilled sections are shown in Figures 3 and 4. The probably Middle Miocene calc-alkaline lava breccias drilled from the base of Hole 832B (lithostratigraphic Unit VII) have no correlates in Hole $833 \mathrm{~B}$ and pre-date the DEZ collision (Hasenaka et al., this volume). Volcanic breccias constituting lithostratigraphic Unit IV in Hole 832B and Unit III in Hole 833B are probably temporally correlated, although Hasenaka et al. (this volume) show that the Hole 833B Unit III clasts are low-K basalts and andesites, closer to lavas from the small backarc island Merelava than the medium- to high- $\mathrm{K}$ lavas of the Central Belt volcanoes bordering the North Aoba Basin and those in Hole 832B Unit IV. This widespread breccia was deposited during or after the major DEZ collision in the latest Pliocene to earliest Pleistocene, which is marked by a major angular unconformity (Fisher et al., this volume) and a biostratigraphic hiatus (Staerker, this volume). A single basaltic clast from this breccia (Unit IV in Hole 832B) has been dated at

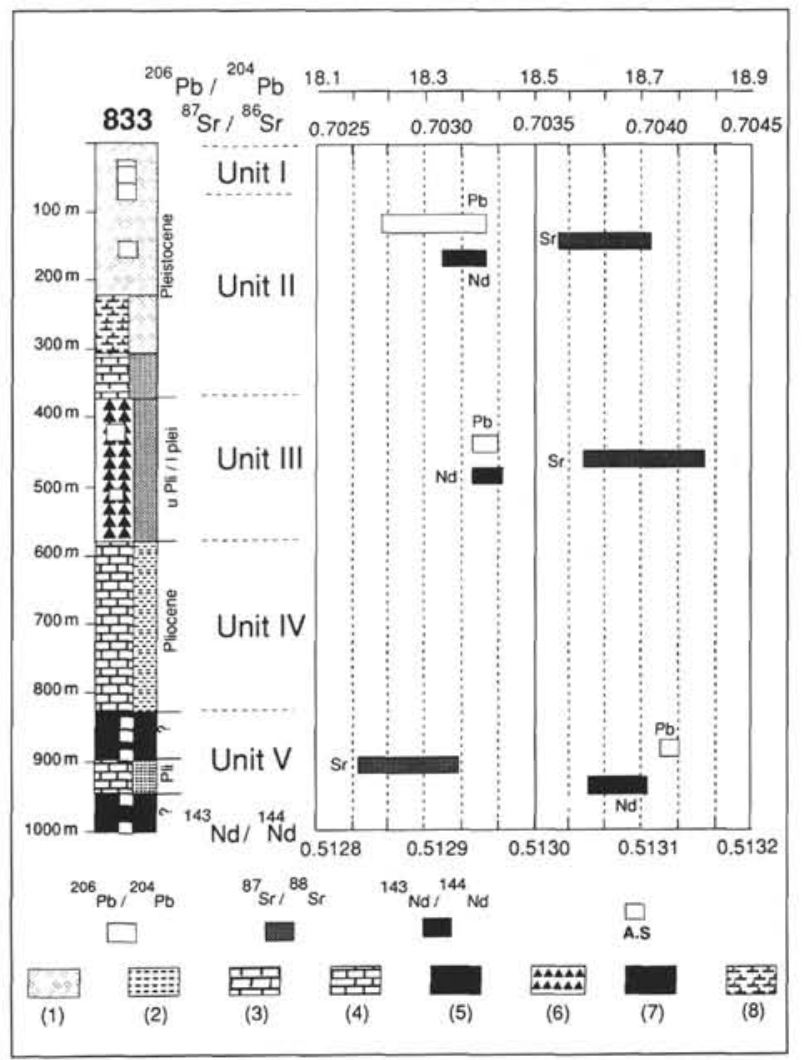

Figure 4. Simplified lithostratigraphic columns and $\mathrm{Pb}, \mathrm{Sr}$, and $\mathrm{Nd}$ isotopic variations of the volcanic and volcaniclastic rocks of Site 832. Key to legend: 1. Volcanic silt/siltstone. 2. Volcanic sandstone-siltstone-claystone. 3. Foraminiferal chalk. 4. Calcareous chalk. 5. Volcanic sand and sandstone. 6. Volcanic breccia. 7. Basaltic sill. 8. Nannofossil ooze. Open squares show levels from which samples were collected for isotopic analysis.

$2.88 \mathrm{Ma}$ (Rex, this volume). Basaltic-andesitic sills dated at $3.3 \mathrm{Ma}$ and $3.6 \mathrm{Ma}$ (Rex, this volume) have intruded Pliocene sediments at the base of Hole 833B. They thus probably predate the DEZ collision and were intruded prior to emplacement of the Unit III volcanic breccia in this Hole.

$\mathrm{Sr}$ and $\mathrm{Nd}$ isotopic data are listed in Table 1 and $\mathrm{Pb}$ isotopic compositions are given in Table 2. Isotopic data for selected samples from volcanic islands of the NHIA are given in Table 3 and averaged isotopic data for pre- and post-DEZ collision arc lavas, reference mantle, and sediments are given in Table 4. These data are plotted in Figures 3 and 4. Clearly, $\mathrm{Pb}$ and $\mathrm{Sr}$ show the most significant isotopic variations.

\section{Site 832}

Volcanic ashes from Unit I and Unit VII volcanic breccia from the base of Hole 832B show almost identical Sr isotopic compositions with ${ }^{87} \mathrm{Sr} /{ }^{86} \mathrm{Sr}=0.7038-0.7040$ : relatively high values for intraoceanic arc rocks. In contrast, the ${ }^{206} \mathrm{~Pb} /{ }^{204} \mathrm{~Pb}$ values for these two units are quite different, with the ashes around 18.12-18.61 (averaging 18.36 for three samples; comparable to lavas from nearby Santa Maria Volcano, 18.17-18.19; Table 3), whereas for the Unit VII breccia this value is $18.80-18.88$ (average of 18.85). The Unit IV volcanic breccia (620-700 mbsf) shows $\mathrm{Pb}$ isotopic values between those of the upper and lower units, with ${ }^{206} \mathrm{~Pb} /{ }^{204} \mathrm{~Pb}=18.28-18.53$, but ${ }^{87} \mathrm{Sr} /{ }^{86} \mathrm{Sr}$ is lower at $0.7027-0.7035$. The Unit IV volcanic breccia $\mathrm{Pb}$ isotopic values (Tables 2 and 3 ) are also intermediate between those for the volcanoes from the southern part of the NHIA and those from central part of the arc (e.g., Santa Maria). It is of interest to note that the ${ }^{206} \mathrm{~Pb} /{ }^{204} \mathrm{~Pb}$ values for Epi volcano (18.47-18.55; Table 3) 
located in the transition region from the collision-affected central section of the NHIA to the north and the unaffected southern NHIA arc volcanoes are also transitional between those from the volcanoes to the north and south.

\section{Site 833}

As for the Unit IV breccia unit in Hole 832B, Hole 833B lithostratigraphic Unit III low-K basaltic to andesitic lava clasts have isotopic values for $\mathrm{Pb}$ intermediate between those for the ashes at the top of the hole and the sills at the base of this hole; Hole 832B Unit IV and Hole 833B Unit III lava clasts show a similar range for ${ }^{206} \mathrm{~Pb}$ and quite similar values for ${ }^{207} \mathrm{~Pb} /{ }^{04} \mathrm{~Pb}$ and ${ }^{207} \mathrm{~Pb} /{ }^{204} \mathrm{~Pb}$. The Unit $\mathrm{V}$ basalticandesitic sills drilled at the base of Hole $833 \mathrm{~B}$ have ${ }^{206} \mathrm{~Pb} /{ }^{204} \mathrm{~Pb}$ values from 18.75-18.79 (averaging 18.77), whereas the upper ashes have low ${ }^{206} \mathrm{~Pb} /{ }^{204} \mathrm{~Pb}$ values $(<18.23-18.37$, averaging 18.31 for three samples), and ${ }^{87} \mathrm{Sr} /{ }^{86} \mathrm{Sr}$ values almost identical to those of the Unit I ashes at Site $832(0.7037-0.7041)$. The sill ${ }^{206} \mathrm{~Pb} /{ }^{204} \mathrm{~Pb}$ values are slightly lower than the Unit VII breccia at Site 832 (18.85), but the sill has very low ${ }^{87} \mathrm{Sr} /{ }^{86} \mathrm{Sr}$ values $(0.7027-0.7032$, averaging 0.7030$)$, among the lowest recorded for the NHIA and comparable only with those from the southern NHIA volcanoes on Futuna, Tanna, and Anatom islands, all of which have ${ }^{87} \mathrm{Sr} /{ }^{86} \mathrm{Sr}$ values around $0.7030-0.7033$ (Table 3 ).

\section{Comparisons within the North Aoba Basin Sites}

\section{The Volcanic Ashes (Unit I)}

The ashes drilled at both Sites 832 and 833 show essentially identical $\mathrm{Pb}, \mathrm{Nd}$, and $\mathrm{Sr}$ isotopic compositions, high $\mathrm{Sr}(>0.7036)$, low $\mathrm{Nd}$ $(<0.5130)$, and generally low ${ }^{206} \mathrm{~Pb} /{ }^{204} \mathrm{~Pb}$ values $(<18.4)$ that match those of the adjacent modern arc volcanoes of Santa Maria, Ambrym, Epi, and Tongoa (Table 3, and Briqueu, 1985). Note that the ash units in both holes show a general decrease in ${ }^{206} \mathrm{~Pb} /{ }^{204} \mathrm{~Pb}$ with decreasing age. As the volcanoes in the southern part of the arc are isotopically distinct from these volcanoes in the central NHIA, it is reasonable to conclude (see also Baker et al., this volume, and Gerard and Person, this volume) that the ashes drilled in the North Aoba Basin are locally derived and represent basin-wide volcano-sedimentary units.

\section{Latest Pliocene Volcanic Breccias: Hole 832B, Unit IV (625.5-702.0 mbsf) and Hole 833B, Unit III (376-578 mbsf)}

Is the latest Pliocene-earliest Pleistocene breccia horizon present in both holes part of the same extensive unit in the North Aoba Basin, and is it compositionally related to the earlier pre-DEZ collision magmatic activity, or to the post-collision magmatic episodes typified by the ashes and recent volcanoes in this part of the NHIA? Pb isotopic data show that these breccia horizons are isotopically very similar and compositionally intermediate between the Hole 832B Unit VII preDEZ collision lava breccias and the post-collision Unit I PleistoceneRecent ashes at both Sites 832 and 833; they are, however, isotopically much closer to the Unit I ashes than the pre-DEZ collision rocks. Major and trace element analyses of clasts from lithostratigraphic Unit III in Hole 833B (Hasenaka et al., this volume) showed that these low-K basalts and andesites are compositionally strikingly similar to lavas from the modern Merelava volcano, which sits astride the western rim of the Northern (Jean Charcot) Trough, a juvenile backarc bain that is rifting the northern portion of the NHIA. Until isotopic analyses are available from Merelava, we cannot test this correlation.

This breccia horizon is located stratigraphically above the main early Pleistocene angular unconformity identified in the North Aoba Basin resulting from the DEZ collision (Fisher et al., this volume; Greene et al., this volume), and records the changing $\mathrm{Pb}$ isotope composition consequent upon collision of the DEZ. This in turn, reflects, a pronounced change in the mantle source for arc volcanism in this region, due to the arrival and ongoing collision of the DEZ.
Table 1. Sr and Nd isotopic data for Sites $828,829,830,831,832$, and 833 volcanics and volcaniclastics.

\begin{tabular}{|c|c|c|c|c|c|c|}
\hline $\begin{array}{l}\text { Core, section, } \\
\text { interval }(\mathrm{cm})\end{array}$ & $\begin{array}{l}\text { Depth } \\
\text { (mbsf) }\end{array}$ & Unit & ${ }^{87} \mathrm{Sr} /{ }^{86} \mathrm{Sr}$ & 2 sigma & ${ }^{143} \mathrm{Nd} /{ }^{144} \mathrm{Nd}$ & 2 sigma \\
\hline \multicolumn{7}{|l|}{$134-828 \mathrm{~A}-$} \\
\hline $12 \mathrm{X}-1,29-31$ & 95.69 & IV & 0.70615 & 0.00003 & & \\
\hline $15 \mathrm{~N}-1,48-52$ & 108.28 & IV & 0.70430 & 0.00005 & 0.51323 & 0.00022 \\
\hline $15 \mathrm{~N}-1,119-120$ & 108.99 & IV & 0.70488 & 0.00003 & 0.51324 & 0.00005 \\
\hline \multicolumn{7}{|l|}{$134-829 \mathrm{~A}-$} \\
\hline $43 R-3,130-133$ & 399 & VII & 0.70450 & 0.00002 & & \\
\hline $59 \mathrm{R}-1,1-3$ & 532.92 & $\mathrm{XV} !$ & 0.70580 & 0.00001 & & \\
\hline $59 \mathrm{R}-1,122-124$ & 534.12 & $\mathrm{XVI}$ & 0.70320 & 0.00007 & & \\
\hline $61 \mathrm{R}-1,41-43$ & 552.71 & $\mathrm{XVI}$ & 0.70325 & 0.00004 & 0.51307 & 0.00001 \\
\hline $61 \mathrm{R}-1,41-43$ & 552.71 & $\mathrm{XVI}$ & 0.70306 & 0.00004 & & \\
\hline $64 \mathrm{R}-1,13-16$ & 581.33 & $\mathrm{XVI}$ & 0.51317 & 0.00002 & & \\
\hline \multicolumn{7}{|l|}{$134-830 \mathrm{~B}-$} \\
\hline $14 \mathrm{R}-1,13-17$ & 175.05 & II & 0.70379 & 0.00004 & & \\
\hline $14 \mathrm{R}-1,47-51$ & 175.371 & I & 0.70331 & 0.00013 & & \\
\hline \multicolumn{7}{|l|}{ 134-831B- } \\
\hline $69 \mathrm{R}-1,43-46$ & 727.23 & IIID & 0.51120 & 0.00005 & & \\
\hline $70 \mathrm{R}-3,37-40$ & 736.77 & IVA & 0.70287 & 0.00004 & 0.51308 & 0.00008 \\
\hline $73 R-2,4-7$ & 765.34 & IV & 0.70282 & 0.00002 & & \\
\hline \multicolumn{7}{|l|}{$134-832 \mathrm{~A}$ - } \\
\hline $1 \mathrm{H}-1,26-27$ & 0.26 & 1 & 0.70404 & 0.00003 & & \\
\hline $14 \mathrm{H}-2,102-103$ & $>102$ & IA & 0.70403 & 0.00003 & 0.51294 & 0.00039 \\
\hline $20 \mathrm{H}-2,124-127$ & 146.04 & 1 & 0.70378 & 0.00004 & & \\
\hline \multicolumn{7}{|l|}{$134-832 \mathrm{~B}$ - } \\
\hline 51R-5, 11-14 & 625.81 & IV & 0.70266 & 0.00006 & & \\
\hline $57 \mathrm{R}-2,119-121$ & 683.89 & IV & 0.70346 & 0.00010 & 0.51300 & 0.00002 \\
\hline $85 \mathrm{R}-1,19-23$ & 952.79 & VII & 0.70446 & 0.00002 & & \\
\hline $87 \mathrm{R}-2,26-32$ & 972.06 & VII & 0.70407 & 0.00004 & 0.51302 & 0.00002 \\
\hline $94 \mathrm{R}-2,29-31$ & 1039.29 & VII & 0.70395 & 0.00003 & & \\
\hline $100 R-4,10-12$ & 1097.10 & VII & 0.70408 & 0.00002 & 0.51309 & 0.00001 \\
\hline \multicolumn{7}{|l|}{$134-833 \mathrm{~A}-$} \\
\hline $3 \mathrm{H}-5,135-137$ & 20.35 & IA & 0.70366 & 0.00004 & & \\
\hline $4 \mathrm{H}-3,8-11$ & 28.58 & IA & 0.70368 & 0.00005 & 0.51292 & 0.00006 \\
\hline $6 \mathrm{H}-4,98-100$ & 40.18 & 1 & 0.70404 & 0.00002 & & \\
\hline $23 X-1,113-115$ & 162.44 & II & 0.70409 & 0.00004 & 0.51306 & 0.00002 \\
\hline \multicolumn{7}{|l|}{ 134-833B- } \\
\hline $36 \mathrm{R}-1,92-94$ & 415.43 & III & 0.70377 & 0.00001 & 0.51295 & 0.00005 \\
\hline $47 \mathrm{R}-2,117-119$ & 501.17 & III & 0.70436 & 0.00006 & 0.51298 & 0.00002 \\
\hline $82 \mathrm{R}-4,28-33$ & 834.28 & $\mathrm{v}$ & 0.70306 & 0.00004 & & \\
\hline $86 R-2,33-36$ & 866.23 & $\mathrm{~V}$ & 0.70317 & 0.00003 & 0.51306 & 0.00002 \\
\hline $90 \mathrm{R}-4,121-123$ & 905.71 & $v$ & 0.70279 & 0.00003 & & \\
\hline $94 \mathrm{R}-2,94-95$ & 944.24 & $\mathrm{v}$ & 0.70270 & 0.00005 & 0.51312 & 0.00002 \\
\hline $99 R-5,86-91$ & 992.36 & V & 0.70318 & 0.00002 & & \\
\hline
\end{tabular}

Notes: ${ }^{87} \mathrm{Sr} /{ }^{86} \mathrm{Sr}$ data are normalized to ${ }^{86} \mathrm{Sr} /{ }^{88} \mathrm{Sr}=0.1194$. Our average ${ }^{87} \mathrm{Sr} /{ }^{86} \mathrm{Sr}$ value for NBS987 standard is $0.71023 \pm 0.00002^{143} \mathrm{Nd} /{ }^{144} \mathrm{Nd}$ data are normalized $10 .{ }^{146} \mathrm{Nd} /{ }^{144} \mathrm{Nd}=0.7219$ and are relative to a value of ${ }^{143} \mathrm{Nd} /{ }^{144} \mathrm{Nd}=0.51114 \pm 0.00001$ for Johnson-Matthey 361 normal solution. Blank = undetermined value.

\section{Rocks from the Bottom of Hole $832 B$ (952.5-1106.5 mbsf)}

The origin of the calc-alkaline Unit VII lava breccia at the base of Hole $832 \mathrm{~B}$ is puzzling. A lava clast from this unit has a $\mathrm{K}-\mathrm{Ar}$ age of $5.66 \mathrm{Ma}$ (Rex, this volume), but occurs in a sedimentary sequence that contains early (?) to middle Miocene microfossils, suggesting that the $\mathrm{K}-\mathrm{Ar}$ age is too young. Rock sequences of this age on Espiritu Santo Island contain abundant coarse volcanic breccias and include common calc-alkaline lavas (Hasenaka et al., this volume) similar to those in Hole 832B (Fisher et al., this volume), and it is therefore likely in our opinion that the $\mathrm{K}$-Ar age does not record the true crystallization age, due to incipient alteration of the sample and Ar loss. If it is a middle Miocene unit, it predates the subduction polarity reversal in this region and provides new information about the isotopic composition of the pre-flip upper mantle that provided arc magmas in the east-facing NHIA. Whatever the case, the analyzed lava fragments in the Unit VII lava breccia in Hole 832B are isotopically unlike lavas from the Santa Maria volcano at the northern rim of the North Aoba Basin (Fig. 2) and also unlike lavas from Ambrym, Epi, and Tongoa volcanoes located slightly further south in the arc (Table 3 , and our unpubl. data). The hypothesis that the breccia is correlated with Miocene volcanics on Espiritu Santo Island further to the west (Fisher et al., this volume) cannot be tested, as no samples of the latter were available for isotopic analysis. However, isotopic data (Tables 1 and 2) for lava breccias and lava clasts from ODP Leg 134 Site 830, 
Table 2. $\mathrm{Pb}$ isotopic data for Sites $828,829,830,831,832$, and 833 volcanics and volcaniclastics.

\begin{tabular}{|c|c|c|c|c|c|c|c|c|c|}
\hline $\begin{array}{l}\text { Core, section, } \\
\text { interval }(\mathrm{cm})\end{array}$ & $\begin{array}{l}\text { Depth } \\
\text { (mbsf) }\end{array}$ & Unit & ${ }^{206 / 204} \mathrm{~Pb}$ & 2 sigma & ${ }^{207 / 204} \mathrm{~Pb}$ & 2 sigma & ${ }^{208 / 204} \mathrm{~Pb}$ & 2 sigma & $\begin{array}{l}\text { Model age } \\
\text { (Ma) }\end{array}$ \\
\hline \multicolumn{10}{|l|}{$134-828 \mathrm{~A}-$} \\
\hline $10 \mathrm{H}-7,43-45$ & 89.83 & III & 18.608 & 0.004 & 15.560 & 0.004 & 38.485 & 0.013 & \\
\hline $12 X-1,29-31$ & 95.67 & IV & 18.618 & 0.007 & 15.568 & 0.007 & 38.339 & 0.018 & \\
\hline $15 \mathrm{~N}-1,48-52$ & 108.28 & IV & 18.613 & 0.005 & 15.566 & 0.005 & 38.344 & 0.015 & \\
\hline $15 \mathrm{~N}-1,122-124$ & 108.99 & IV & 18.561 & 0.006 & 15.518 & 0.006 & 38.142 & 0.016 & \\
\hline \multicolumn{10}{|l|}{ 134-829A- } \\
\hline $43 \mathrm{R}-3,130-133$ & 399 & VII & 18.727 & 0.004 & 15.550 & 0.004 & 38.248 & 0.012 & \\
\hline $59 \mathrm{R}-1,1-3$ & 532.92 & XVI & 18.865 & 0.004 & 15.659 & 0.004 & 38.862 & 0.012 & \\
\hline $59 \mathrm{R}-1,122-124$ & 534.12 & XVI & 18.602 & 0.004 & 15.609 & 0.004 & 38.500 & 0.013 & \\
\hline $61 \mathrm{R}-1,41-43$ & 552.71 & XVI & 18.569 & 0.005 & 15.601 & 0.005 & 38.474 & 0.014 & \\
\hline $61 \mathrm{R}-1,41-43$ & 552.71 & XVI & 18.582 & 0.008 & 15.627 & 0.008 & 38.563 & 0.022 & \\
\hline $64 \mathrm{R}-1,13-16$ & 581.33 & XVI & 18.616 & 0.008 & 15.619 & 0.008 & 38.547 & 0.022 & \\
\hline \multicolumn{10}{|l|}{ 134-830B- } \\
\hline $14 \mathrm{R}-1,13-17$ & 175.03 & II & 18.696 & 0.003 & 15.556 & 0.004 & 38.388 & 0.012 & \\
\hline $14 \mathrm{R}-1,47-51$ & 175.37 & II & 18.754 & 0.003 & 15.575 & 0.004 & 38.570 & 0.011 & \\
\hline \multicolumn{10}{|l|}{ 134-831B- } \\
\hline $70 \mathrm{R}-3,37-40$ & 736.77 & IVA & 18.500 & 0.003 & 15.499 & 0.004 & 38.048 & 0.012 & \\
\hline $73 R-2,4-7$ & 765.34 & IV & 18.511 & 0.004 & 15.526 & 0.004 & 38.123 & 0.013 & \\
\hline \multicolumn{10}{|l|}{$134-832 \mathrm{~A}-$} \\
\hline $1 \mathrm{H}-1,26-27$ & 0.26 & I & 18.118 & 0.003 & 15.497 & 0.004 & 38.275 & 0.013 & +165 \\
\hline $14 \mathrm{H}-2,102-103$ & 102 & I & 18.361 & 0.004 & 15.559 & 0.004 & 38.518 & 0.013 & +111 \\
\hline $20 \mathrm{H}-2,124-127$ & 146.04 & I & 18.613 & 0.004 & 15.598 & 0.004 & 38.639 & 0.016 & +1 \\
\hline \multicolumn{10}{|l|}{ 134-832B- } \\
\hline $51 \mathrm{R}-5,11-14$ & 625.81 & IV & 18.530 & 0.005 & 15.529 & 0.005 & 38.097 & 0.015 & -90 \\
\hline 57R-2, 119-121 & 683.89 & IV & 18.275 & 0.003 & 15.506 & 0.003 & 38.297 & 0.001 & +60 \\
\hline $85 R-1,19-23$ & 952.79 & VII & 18.866 & 0.003 & 15.583 & 0.003 & 38.624 & 0.011 & -233 \\
\hline $87 R-2,26-32$ & 972.06 & VII & 18.796 & 0.003 & 15.570 & 0.004 & 38.564 & 0.011 & -208 \\
\hline 94R-2, 29-31 & 1039.29 & VII & 18.852 & 0.008 & 15.587 & 0.007 & 38.662 & 0.020 & -210 \\
\hline $100 \mathrm{R}-4,10-12$ & 1097.1 & VII & 18.879 & 0.004 & 15.608 & 0.005 & 38.750 & 0.018 & -182 \\
\hline \multicolumn{10}{|l|}{ 134-833A- } \\
\hline $3 \mathrm{H}-5,135-137$ & 20.35 & IA & 18.332 & 0.003 & 15.515 & 0.004 & 38.402 & 0.012 & +35 \\
\hline $4 \mathrm{H}-3,8-11$ & 28.58 & IA & 18.233 & 0.004 & 15.536 & 0.005 & 38.392 & 0.015 & +160 \\
\hline $6 \mathrm{H}-4,97-100$ & 40.18 & I & 18.372 & 0.003 & 15.541 & 0.003 & 38.493 & 0.010 & +62 \\
\hline $23 X-1,113-115$ & 162.44 & II & 18.432 & 0.003 & 15.523 & 0.003 & 38.317 & 0.011 & -26 \\
\hline \multicolumn{10}{|l|}{ 134-833B- } \\
\hline $36 \mathrm{R}-1,92-94$ & 415.43 & III & 18.452 & 0.004 & 15.550 & 0.003 & 38.437 & 0.011 & +20 \\
\hline $47 R-2,117-119$ & 501.17 & III & 18.413 & 0.012 & 15.582 & 0.011 & 38.611 & 0.029 & +120 \\
\hline $82 \mathrm{R}-4,28-33$ & 834.28 & V & 18.761 & 0.003 & 15.562 & 0.004 & 38.505 & 0.011 & -197 \\
\hline $86 \mathrm{R}-2,33-36$ & 866.23 & V & 18.751 & 0.003 & 15.515 & 0.004 & 38.344 & 0.013 & -303 \\
\hline $90 R-4,121-123$ & 905.71 & V & 18.776 & 0.003 & 15.515 & 0.004 & 38.344 & 0.013 & -323 \\
\hline 94R-2, 94-95 & 944.24 & $\mathrm{~V}$ & 18.792 & 0.004 & 15.583 & 0.005 & 38.568 & 0.015 & -175 \\
\hline $99 \mathrm{R}-5,86-91$ & 992.36 & V & 18.761 & 0.004 & 15.544 & 0.004 & 38.421 & 0.012 & -240 \\
\hline
\end{tabular}

Notes: These data were corrected with a mass discrimination factor of $0.13 \%$ per atomic unit difference. The errors are assumed to be less than $0.3 \%$ for ${ }^{206} \mathrm{~Pb} /{ }^{204} \mathrm{~Pb}$, ${ }^{207} \mathrm{~Pb} /{ }^{204} \mathrm{~Pb}$, and ${ }^{208} \mathrm{~Pb} /{ }^{204} \mathrm{~Pb}$ ratios. Results for NBS 981 standard during the work period are: ${ }^{206} \mathrm{~Pb} /{ }^{204} \mathrm{~Pb}=16.947 \pm 0.008,{ }^{207} \mathrm{~Pb} /{ }^{204} \mathrm{~Pb}=15.504 \pm 0.008$, and ${ }^{208} \mathrm{~Pb} /{ }^{204} \mathrm{~Pb}=36.746$ \pm 0.017 . Blank $=$ undefined value.

interpreted to have derived from the Western Belt islands, show ${ }^{206} \mathrm{~Pb} /{ }^{204} \mathrm{~Pb}$ values $(18.7-18.75)$ that are very similar to those for the Hole 832B Unit VII lava breccia (18.80-18.88) and only slightly less radiogenic $\mathrm{Sr}$ isotopic values (0.7033-0.7038 compared with $0.7040-0.7045$ for the Site 832 breccia). We note below the possibility that despite the strong leaching procedure applied prior to isotopic analysis of these samples, the ${ }^{87} \mathrm{Sr} /{ }^{86} \mathrm{Sr}$ values for this breccia unit may be higher than primary values because of seawater alteration. If this is the case, the Unit VII calc-alkaline lava breccias become even closer isotopically to those from the Western Belt islands.

\section{Basaltic Sills from the Base of Hole 833B (834-991.5 mbsf)}

The Middle Pliocene sills at the base of Hole $833 \mathrm{~B}$ predate the widespread early Pleistocene angular unconformity in this part of the North Aoba Basin, and presumably predate collision of the DEZ. These sills have ${ }^{206} \mathrm{~Pb} /{ }^{204} \mathrm{~Pb}$ values from $18.75-18.79$, close to those for the basal Hole 832B Unit VII breccias (18.80-18.88) and notably higher than ${ }^{206} \mathrm{~Pb} /{ }^{204} \mathrm{~Pb}$ values for the upper ashes and latest Pliocene volcanic breccias at both Sites (avg. 18.375). They seem, therefore, to be related to the pre-DEZ collision magmatic episode. However, their ${ }^{87} \mathrm{Sr} /{ }^{86} \mathrm{Sr}$ values are equivalent to those for the southern NHIA volcanoes and are significantly lower than those for the Unit VII breccia in Hole 832B $(0.7027-0.7032$ vs. $0.7040-0.7045)$. Although this may reflect a primary difference, it is hard to avoid an alternative interpretation that the relatively high ${ }^{87} \mathrm{Sr} /{ }^{86} \mathrm{Sr}$ values for the clasts in the Unit VII breccias are due to seawater alteration, despite the strong leaching procedure. The coherent and massive intrusive sills avoided such seawater interaction and have retained their primary $\mathrm{Sr}$ isotopic compositions.

\section{DISCUSSION}

The isotopic data presented above raise some interesting problems, of both local (i.e., NHIA) and global (all intra-oceanic island arcs) significance. These problems are discussed below.

\section{Sr-Nd Relationships}

In the ${ }^{143} \mathrm{Nd} /{ }^{144} \mathrm{Nd}-{ }^{87} \mathrm{Sr} /{ }^{86} \mathrm{Sr}$ diagram (Fig. 5), the field for lavas from intra-oceanic arcs, as typified by the Marianas and our data for the NHIA, falls mainly below the mid-ocean ridge basalt (MORB) compositional field and generally extends at near-constant ${ }^{143} \mathrm{Nd} /{ }^{144} \mathrm{Nd}$ towards higher ${ }^{87} \mathrm{Sr} /{ }^{86} \mathrm{Sr}$ values. This feature has been attributed to mixing of several different components in the source of these intra- 
Table 3. Selected $\mathrm{Sr}$, Nd, and $\mathrm{Pb}$ isotopic data for lavas from Santa Maria, Epi-Tongoa, Tanna, Anatium, and Futuna islands in the New Hebrides Arc (Briqueu, 1985).

\begin{tabular}{lrlllll}
\hline \multicolumn{1}{c}{ Samples } & ${ }^{87} \mathrm{Sr} /{ }^{86} \mathrm{Sr}$ & ${ }^{143} \mathrm{Nd} /{ }^{143} \mathrm{Nd}$ & ${ }^{200204} \mathrm{~Pb}$ & ${ }^{207 / 204} \mathrm{~Pb}$ & ${ }^{208 / 204} \mathrm{~Pb}$ & $\begin{array}{r}\mathrm{Pb} \text { Model } \\
\text { ages (Ma) }\end{array}$ \\
\hline Northern Islands & & & & & & \\
Santa Maria 18 & 0.70395 & 0.51298 & 18.168 & 15.512 & 38.273 & +159 \\
Santa Maria 22 & 0.70389 & 0.51299 & 18.193 & 15.506 & 38.253 & +126 \\
Santa Maria 1 & 0.70405 & 0.51294 & 18.170 & 15.521 & 38.303 & +177 \\
Epi 8 & 0.70397 & 0.51297 & 15.545 & 15.566 & 38.449 & -17 \\
Epi 26 & 0.70363 & - & 18.472 & 15.553 & 38.519 & +11 \\
Southern Islands & & & & & & \\
Tanna 72 & 0.70309 & 0.51298 & 18.658 & 15.542 & 38.357 & -164 \\
Aneytium 42 & 0.70325 & 0.51304 & 18.805 & 15.554 & 38.435 & -253 \\
Futuna 2 & 0.70306 & 0.51304 & 18.789 & 15.563 & 38.465 & -271 \\
Loyalty Plateau (DSDP Leg 30) & & & & & \\
286-9.3-68.70 & 0.70335 & 0.512991 & 18.466 & 15.550 & 38.405 & 10 \\
286-27.2-21.23 & 0.70322 & 0.513115 & 18.523 & 15.496 & 38.041 & -161 \\
286-36.1-110.112 & 0.70380 & 0.513166 & 18.529 & 15.485 & 38.070 & -193 \\
\hline
\end{tabular}

Table 4. Isotopic characteristics for possible end-member components for mixing to produce the pre- and postcollision volcanics.

\begin{tabular}{|c|c|c|c|c|c|}
\hline & \multicolumn{2}{|c|}{ New Hebrides magmatisms } & \multicolumn{3}{|c|}{ Some mantle references } \\
\hline & Before collision & After collision & Sediments & E.M. I & DUPAL \\
\hline${ }^{206} \mathrm{~Pb} /{ }^{204} \mathrm{~Pb}$ & 18.75 & 18,10 & $18.6-19$ & 17.30 & 18.10 \\
\hline${ }^{2077} \mathrm{~Pb} /{ }^{204} \mathrm{~Pb}$ & 15.50 & 15.49 & $15.62-15.68$ & 15.43 & 15.52 \\
\hline${ }^{208} \mathrm{~Pb}{ }^{204} \mathrm{~Pb}$ & 38.25 & 38.20 & $38.7-39.2$ & 38.30 & 38.50 \\
\hline${ }^{87} \mathrm{Sr} /{ }^{86} \mathrm{Sr}$ & 0.7027 & 0.7037 & $0.7072-0.709$ & 0.7055 & \\
\hline${ }^{143} \mathrm{Nd} /{ }^{144} \mathrm{Nd}$ & 0.51317 & 0.51295 & $0.5126-0.5127$ & 0.5123 & \\
\hline
\end{tabular}

Note: Data are from Richardson et al. (1982), Zartman and Doe (1981), Zartman and Haines (1988), and Dupré and Allègre (1983). Blank = undetermined value, E.M. I = enriched mantle Type 1, DUPAL: term proposed by Hart (1984).

oceanic arc lavas (De Paolo and Johnson, 1979; White and Patchett, 1984; Von Drach et al., 1986). These components include (1) a depleted upper oceanic mantle wedge (DM), to explain the high ${ }^{143} \mathrm{Nd} /$ ${ }_{144} \mathrm{Nd}$ values relative to bulk Earth; (2) seawater, to account for the selective enrichment of radiogenic ${ }^{87} \mathrm{Sr}$; and (3) a component with a lower ${ }^{143} \mathrm{Nd} /{ }^{144} \mathrm{Nd}$ value than Pacific-Atlantic MORB, since the intraoceanic arc lava field extends to lower ${ }^{143} \mathrm{Nd} /{ }^{144} \mathrm{Nd}$ values than the MORB array. This component may be in a pre-existing enriched or undepleted part of the mantle wedge, or may be a new component, such as pelagic sediment, recycled into the mantle wedge via subduction. Whatever the case, at least two components are necessary to modify DM towards the field for intra-oceanic arc lavas.

The NHIA lavas conform to this general pattern. Their Nd isotope ratios $(\sim 0.5132-0.5129)$ are lower than MORB, and their Sr isotope values vary significantly, from 0.7027 (base of Hole 833B) to 0.7043 (on Ambrym and Santa Maria volcanoes; Table 3 and our unpubl. data). This same variation is observed both spatially, at the scale of the entire NHIA (Briqueu, 1985; Javoy et al., 1986; Peate et al., 1991), and temporally in Site 832 (if the Unit VII lava breccias analyzed for $\mathrm{Sr}$ isotopes are seawater-altered, as suggested above) and Site 833 (Figs. 3 and 4).

The collision of the DEZ with the arc may be responsible for the enhanced radiogenic $\mathrm{Sr}$ in the post-collision lavas. For example, the basaltic upper part of the DEZ is strongly seawater-altered (Table 2, and Coltorti et al., this volume; Collot, Greene, Stokking, et al., 1992), much more so, for example, than the basaltic crust of the Loyalty Basin subducting beneath the southern part of the arc that was drilled during DSDP Leg 30 (Briqueu and Lancelot, 1982). Dehydration of this more altered and ${ }^{87} \mathrm{Sr}$-rich basaltic crust beneath the central part of the arc may be one factor responsible for the more radiogenic $\mathrm{Sr}$ in the central arc lavas.

An alternative explanantion for the excess radiogenic $\mathrm{Sr}$ in the central arc volcanoes may be that DEZ collision with the small North Fiji Basin plate that supports the arc produced regional crustal-scale fracturing that allowed seawater to find more ready access to shallow magma chambers where fractionation of these magmas was occur-

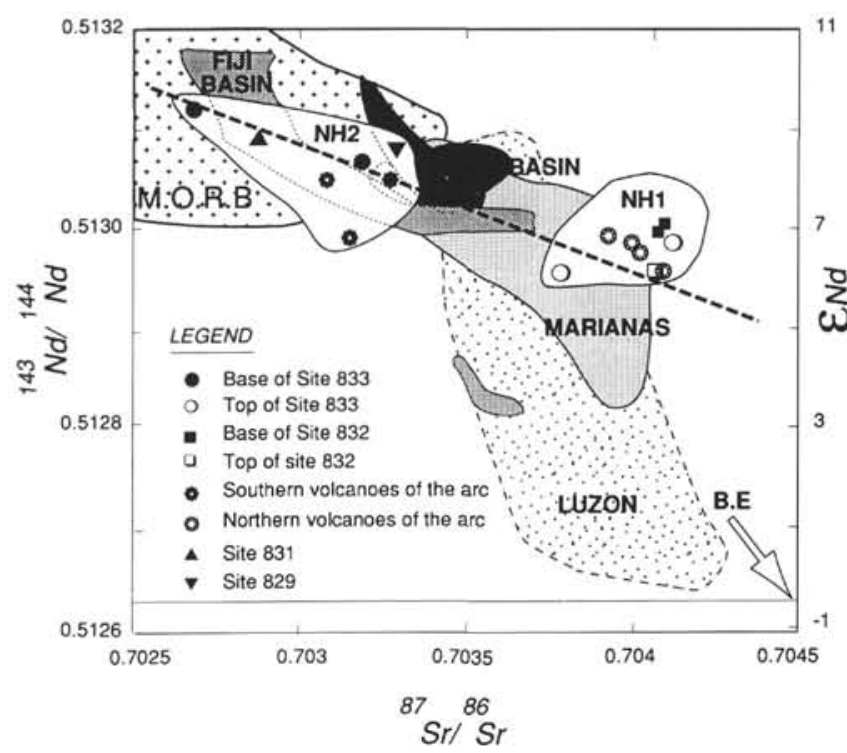

Figure $5 .{ }^{143} \mathrm{Nd} /{ }^{144} \mathrm{Nd}$ vs ${ }^{87} \mathrm{Sr} /{ }^{86} \mathrm{Sr}$ relationships for the New Hebrides Island Arc and several other intra-oceanic arcs (Marianas [Stern et al., 1991], Luzon [Chen et al., 1990], Lau Basin [Boespflug, 1990; Boespflug et al., 1990], and Pacific-Atlantic MORB). The New Hebrides data plot in two distinct fields. $\mathrm{NHI}$ is defined by volcanic ashes from Unit 1 at Sites 832 and 833 and by lavas from volcanoes in the central part of the arc (open symbols). NH2 is defined by drilled volcanic breccia and sill samples, and by lavas from volcanoes located well away from the collision zone in the southern part of the arc (filled symbols). B.E. represents present-day bulk earth isotopic values.

ring. This process is well documented for Santa Maria volcano, in which the $\mathrm{Sr}$ isotope ratio is well correlated with indices of fractionation such as Th content (Briqueu, 1985).

A final hypothesis for radiogenic Sr enrichment in this part of the arc may be that the mantle source tapped to produce these magmas was long-term enriched in ${ }^{87} \mathrm{Sr}$. This model is discussed more fully following presentation of the $\mathrm{Pb}$ isotopic data.

\section{Pb-isotope Relationships}

Many lavas in intra-oceanic island arcs carry a $\mathrm{Pb}$ isotope signature that demands a component derived from subducted pelagic sediments (Sun, 1980; White and Dupre, 1986; Ben Othman et al., 1989), and even a very small amount of pelagic sediment can strongly affect the $\mathrm{Pb}$ isotope composition of island arc lavas derived from a source dominated by depleted mantle. Lava suites for which pelagic sediment contamination of the source has occurred usually show compositional fields on ${ }^{207} \mathrm{~Pb} /{ }^{204} \mathrm{~Pb}$ and ${ }^{208} \mathrm{~Pb} /{ }^{204} \mathrm{~Pb}$ versus ${ }^{206} \mathrm{~Pb} /{ }^{204} \mathrm{~Pb}$ diagrams that extend from the MORB array towards the field for pelagic sediments.

Our $\mathrm{Pb}$ data (Figs. 6 and 7) show that the older, pre-DEZ collision lavas and breccias drilled in the two North Aoba Basin sites are compositionally very close to the lavas from volcanoes in the southern part of the arc, remote from the DEZ collision. Both groups are interpreted to be derived from the ubiquitous, regional depleted sub-oceanic mantle with a small amount of contamination by pelagic sediment. However, a similar source cannot be ascribed to the post-DEZ collision volcanism in the central part of the arc. Lavas from volcanoes in this region and from the younger sections of Holes 832B and 833B show profoundly different ${ }^{206} \mathrm{~Pb} /{ }^{204} \mathrm{~Pb}$ values $(18.4-18.1)$ compared with the older drilled lavas and those from the southern New Hebrides Arc volcanoes (18.7-18.9), and they also extend to more radiogenic ${ }^{208} \mathrm{~Pb} /{ }^{204} \mathrm{~Pb}$ ratios. (Figs. 6). The dominant upper mantle source of these magmas could not have been the depleted sub-oceanic mantle source (DM) of the older lava breccias in Hole 832B and the sills at the base of Hole 833B, and the southern arc volcanoes. 


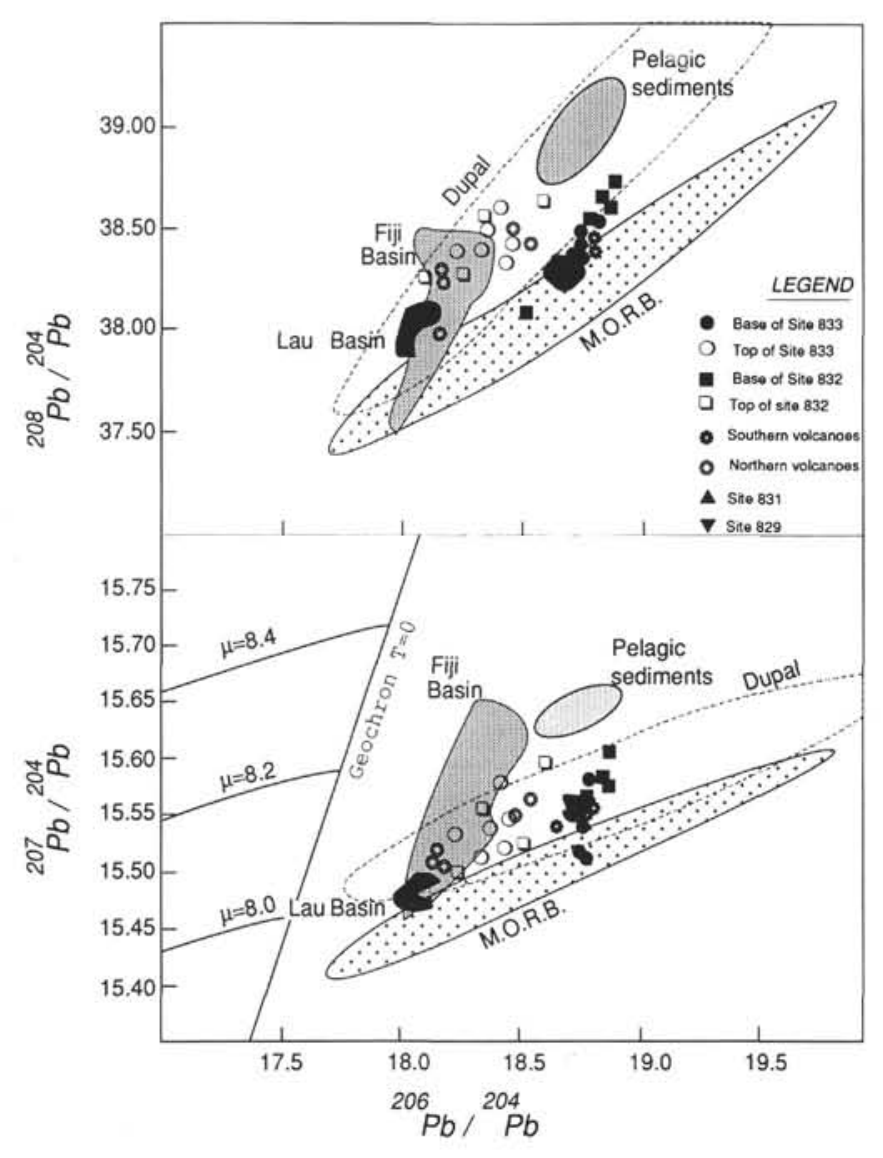

Figure 6. ${ }^{207} \mathrm{~Pb} /{ }^{204} \mathrm{~Pb}$ vs. ${ }^{206} \mathrm{~Pb} /{ }^{204} \mathrm{~Pb}$ and ${ }^{208} \mathrm{~Pb} /{ }^{204} \mathrm{~Pb}$ vs. ${ }^{206} \mathrm{~Pb} /{ }^{204} \mathrm{~Pb}$ for samples from Sites 832 and 833 (Table 2) and some representative modern lavas from New Hebrides Island Arc volcanoes (Table 3). For the Nd-Sr data for the New Hebrides Island Arc rocks, the $\mathrm{Pb}-\mathrm{Pb}$ data plot in two distinct fields.

In summary, compared to the pre-collision magmas that are derived from a "normal" pelagic sediment-contaminated DM source, the more recent lavas and ashes have notably lower ${ }^{206} \mathrm{~Pb}$, and slightly more enriched ${ }^{207} \mathrm{~Pb}$ and ${ }^{208} \mathrm{~Pb}$ values, as well as having higher ${ }^{87} \mathrm{Sr} /{ }^{86} \mathrm{Sr}$ values. These are signatures inherited from an "abnormal" mantle source. Lava breccias in Unit IV in Hole 832B and Unit III in Hole $833 \mathrm{~B}$, temporally located between these two isotopic suites, are also isotopically intermediate between these two extremes. No part of the subducting oceanic crust in this region, including the DEZ, and the Loyalty Basin oceanic crust (Briqueu and Lancelot, 1982), nor the pre-subduction reversal oceanic lithosphere in this regions (as indicated by middle Miocene Hole 832B Unit VII clasts), has $\mathrm{Pb}$ isotopic similarities to the low ${ }^{206} \mathrm{~Pb} /{ }^{204} \mathrm{~Pb}$, relatively ${ }^{87} \mathrm{Sr} /{ }^{86} \mathrm{Sr}$-enriched mantle source of the post-collision lavas, the source of which must therefore be located within the over-riding plate.

\section{Nature of the Enriched Mantle Source}

Several alternative explanations may be proposed for the origin of the isotopically enriched abnormal source of the post-collisional volcanics in the central NHIA.

\section{Recently Recycled Crustal Materials}

As noted above, the low ${ }^{206} \mathrm{~Pb} /{ }^{204} \mathrm{~Pb}$ values of the post-collision lavas in the central part of the arc indicate that this signature cannot be derived from components on the subducting plate, including pelagic sediments, altered DEZ basalts or Bouganville Guyot andesites, or

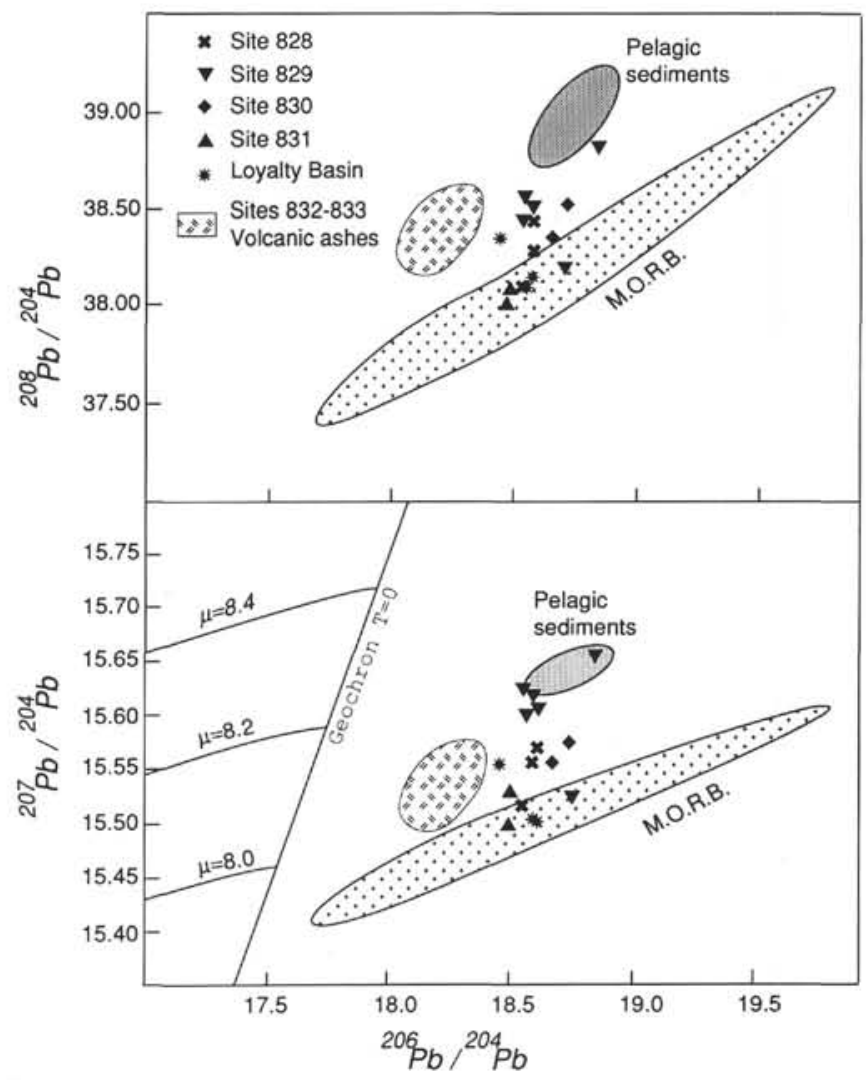

Figure 7. $\mathrm{Pb}$ isotopic data for samples from Sites 828 to 831 . None of these rocks being subducted can explain the low ${ }^{206} \mathrm{~Pb} /{ }^{204} \mathrm{~Pb}$ values for the post-DEZ collision arc magmatism. All data plot on the left side of the field defined by ashes from Units I at both Sites 832 and 833 , and by active volcanoes located around the margins of the Aoba Basin.

Loyalty Basin oceanic crust. Furthermore, the post-Miocene collision of the DEZ with the NHIA is too young for it to have generated, via metasomatic processes and subsequent radioactive decay of $U$ and $\mathrm{Th}$, the isotopic characteristics of the post-collision basalts. The isotopic signature of the abnormal mantle source is clearly much older than the time of collision of the DEZ, and our calculations using the DM growth curve (Zartman and Doe, 1981; Zartman and Haines, 1988) show that at least 500 m.y. of mantle differentiation are necessary to produce the observed $\mathrm{Pb}$ isotope characteristics.

\section{Continental Crust}

Although crustal melting has been invoked for the genesis of felsic lavas elsewhere in the NHIA (Efate Island; Coulon et al., 1979), this hypothesis is not applicable to the postcollision lavas from the central part of the arc. There are no known old continental crustal blocks on the subducting plate, and given the identical ${ }^{87} \mathrm{Sr} /{ }^{86} \mathrm{Sr}$ values for the Efate felsic lavas and associated basalts $(0.7041)$, it is possible that the felsic rocks were produced by melting of similar basalts at the base of the crust.

\section{Anomalous Enriched Upper Mantle}

The isotopic features of the postcollision basalts are similar in many respects to those of the Indian Ocean upper mantle (Dupre and Allegre, 1983; Hamelin and Allegre, 1985), being somewhat enriched in radiogenic $\mathrm{Sr}$ and $\mathrm{Pb}$ compared to typical Atlantic and Pacific MORB and suboceanic upper mantle. Hart (1984) showed that a band of anomalously enriched mantle (termed DUPAL) circles the globe in 
the Southern Hemisphere mid-latitudes and suggested that evidence for DUPAL mantle might be found in arc and backarc basins lavas of island arc systems in this region. We believe that the isotopic data for the post-collisional lavas from the central New Hebrides Island Arc reflect the involvement of an Indian Ocean-type mantle component, and we note that isotopic evidence for the the involvement of this same mantle source has been found in Philippine Sea crust and adjacent Mariana-Izu-Bonin arc volcanic rocks (Mukasa et al., 1987; Hochstaedter et al., 1990) and in Lau back-arc basin crust (Loock et al., 1991).

\section{Location of the Enriched Source}

Seismologic sections of the NHIA at several locations along the arc (Pascal et al., 1978; Goula and Pascal, 1979; Louat et al., 1988) show that in the southern part of the arc, where only "normal" mantle is contributing to the arc magmatism, the subducted slab is continuous and the top of the slab is only $\sim 130 \mathrm{~km}$ below the arc volcanic islands of Tanna and Anatom (Louat et al., 1988) and $80 \mathrm{~km}$ below Matthew island (Monzier et al., unpubl. data). Below these islands, the leading edge of the subducted slab may lie around $180 \mathrm{~km}$ depth. Further north, the length of the subducted slab increases sharply, and seismic events at depths as great as $350 \mathrm{~km}$ are recorded (Louat et al., 1988). In contrast to the relatively simple southern section of the NHIA, in the central part of the NHIA slab configuration is more complex. Louat et al. (1988) suggested, on the basis of earthquake foci in the central NHIA, that the subducted slab may be broken and have a seismic gap from $\sim 50-150 \mathrm{~km}$ depth. Prevot et al. (1991) suggest that this seismic gap represents a thermal anomaly of some $750^{\circ} \mathrm{C}$, which alters the physical properties of the subducted slab beneath this region. In this region, the top of the slab is about $150-200 \mathrm{~km}$ beneath the arc volcanoes.

Arc magmas forming the islands of Tanna and Erromango in the southern part of the NHIA are mainly low- to medium-K arc basalts, although high-K basalts are recorded (Dupuy et al., 1982; Eggins, 1989; Monzier et al., unpubl. data), and our data show these to be isotopically strikingly similar to those erupted pre-DEZ collision in the central NHIA. Pre-DEZ collision Mio-Pliocene lavas on Pentecost and Maewo islands (our unpublished data), correlated lavas dredged from the northwest slope of Pentecost (D24: Johnson et al., 1988 ), and the basal lava breccias and sills in Holes 832B and 833B are also medium- $\mathrm{K}$ arc basalts with subordinate but distinct high- $\mathrm{K}$ basalts (e.g., the Hole 833B sills).

An important observation from the wholerock major and trace element geochemical data presented in Hasenaka et al. (this volume) is that the pre-DEZ collision Pliocene sills show distinctly high-K to shoshonitic, transitional alkaline compositions, yet still have isotopic signatures typical of the pre-collision magma grouping, with high ${ }^{206} \mathrm{~Pb} /{ }^{204} \mathrm{~Pb}(18.75-18.79)$ and low ${ }^{87} \mathrm{Sr} /{ }^{86} \mathrm{Sr}(0.7027-0.7032)$. This clearly demonstrates that the anomalous low ${ }^{206} \mathrm{~Pb} /{ }^{204} \mathrm{~Pb}$ isotopic signature is not simply correlated with alkalinity of the magma type, which relates more or less to depth of magma segregation from source peridotite. A hypothesis of a two-layered mantle, with an upper normal sub-arc oceanic-type upper mantle and a lower anomalous enriched upper mantle would seem to be precluded by the normal isotopic values for the relatively deep-derived Pliocene sills in Hole 833B.

As noted above, available $\mathrm{Pb}$ and $\mathrm{Sr}$ isotopic data for the $\mathrm{DEZ}$ suggest that it carries no $l w^{206} \mathrm{~Pb} /{ }^{204} \mathrm{~Pb}$ rocks, and thus fluids derived from the DEZ rising into the overlying mantle wedge are unlikely to be the source of the low ${ }^{206} \mathrm{~Pb} /{ }^{204} \mathrm{~Pb}$ in the collision zone rocks. It remains to identify the source of the anomalous component that carries the isotopic signature of enriched mantle described above, characterized by ${ }^{206} \mathrm{~Pb} /{ }^{204} \mathrm{~Pb}<18.4$ (probably $<18.1$ ), and ${ }^{87} \mathrm{Sr} /{ }^{86} \mathrm{Sr}$ $>0.7039$. It may be related in some way to the break in the subducted slab hypothesized to exist beneath the central part of the NHIA.

\section{CONCLUSIONS}

Prior to the collision of the DEZ, arc magmatism along the New Hebrides Island Arc was typical of intra-oceanic arcs, with a dominant depleted suboceanic upper mantle (DM) being contaminated by components from the subducted slab. Both relatively HFSE- and LILEenriched transitional alkaline arc basalts and more typical low- to medium- $\mathrm{K}$ arc basalts occur in most volcanoes along the arc from its southern end to the DEZ collision zone, and the former occur as Pliocene-age sills in Hole 833B. The $\mathrm{Sr}-\mathrm{Nd}-\mathrm{Pb}$ isotopic compositions of these lavas, whether of high-K or normal affinities, are characterized by high ${ }^{206} \mathrm{~Pb} /{ }^{204} \mathrm{~Pb}(>18.56)$ and relatively low ${ }^{87} \mathrm{Sr} /{ }^{86} \mathrm{Sr}(<0.7033)$. Pre-subduction reversal Middle Miocene calc-alkaline lavas breccias from the base of Hole $832 \mathrm{~B}$ have very similar high ${ }^{206} \mathrm{~Pb} /{ }^{204} \mathrm{~Pb}$, although their ${ }^{87} \mathrm{Sr} /{ }^{86} \mathrm{Sr}(0.7040-0.7045)$ are probably sea-water altered and were probably derived from the same ambient subarc oceanic depleted mantle.

A major change in the isotopic composition of erupted lavas occurred as a result of DEZ collision, which in this part of the arc probaby occurred between 2 and $1.5 \mathrm{Ma}$ (Taylor et al., this volume), and produced a widespread unconformity in the North Aoba Basin. This led to a significant decrease in ${ }^{206} \mathrm{~Pb} /{ }^{204} \mathrm{~Pb}$ (to values as low as 18.1 ) and increases in ${ }^{87} \mathrm{Sr} /{ }^{86} \mathrm{Sr}$ (to 0.7040 ) and to a lesser degree ${ }^{207} \mathrm{~Pb} /{ }^{204} \mathrm{~Pb}$ and ${ }^{208} \mathrm{~Pb} /{ }^{204} \mathrm{~Pb}$ in greater than $2 \mathrm{Ma}$ lavas. The new, anomalously-enriched mantle source involved in the post-DEZ collision magma genesis cannot have been produced from DM by recent subduction-contamination, nor is it related to components derived from the subducting oceanic plate, including the DEZ. Rather, it is characterized by an ancient enrichment $(>500 \mathrm{Ma})$ and is isotopically very similar to Indian Ocean-type anomalous suboceanic mantle. We have no explanation for the source of this anomalous upper mantle component, though we note that it is unambiguously related to the collision of the central part of the NHIA with the DEZ.

\section{REFERENCES*}

Auzende, J.-M., Lafoy, Y., and Marsset, B., 1988. Recent geodynamic evolution of the North Fiji Basin (Southwest Pacific). Geology, 16:925-929.

Barsdell, M., Smith, I.E.M., and Sporli, K.B., 1982. The origin of reversed geochemical zoning in the Northern New Hebrides Volcanic Arc. Contrib. Mineral. Petrol., 81:148-155.

Ben Othman, D., White, W.M., and Patchett, J., 1989. The geochemistry of marine sediments, island arc magma genesis and crust-mantle recycling. Earth Planet. Sci. Lett., 94:1-21.

Birck, J.L., and Allègre, C.J., 1978. Chronology and chemical history of the parent body of basaltic achondrites studied by the ${ }^{87} \mathrm{Rb}^{86} \mathrm{Sr}$ method. Earth Planet. Sci. Lett., 39:37-51.

Boespflug, X., 1990. Evolution geodynamique et geochimique des bassins arrieres-arcs: exemples des bassins d'Okinowa, de Lau et Nord Fidjien [These]. Univ. de Bretagne Occidentale.

Boespflug, X., Dosso, L., Bougault, H., and Joron, J.L., 1990. Trace element and isotopic ( $\mathrm{Sr}$ and $\mathrm{Nd}$ ) geochemistry of volcanic rocks from the Lau Basin. In von Stackelberg, U., and von Rad, U. (Eds.), Geological Evolution and Hydrothermal Activity in the Lau and North Fiji Basins, Southwest Pacific Ocean (Results of SONNE Cruise SO-35). Geol. Jahrb., Reihe D, 92:503-516.

Briqueu, L., 1985. Etude du magmatisme associé au zones de subduction á l'aide de traceurs geochimiques multiples: elements traces et rapports isotopiques ${ }^{87} \mathrm{Sr} /{ }^{86} \mathrm{Sr}$ et ${ }^{143} \mathrm{Nd} /{ }^{144} \mathrm{Nd}$ [These]. Univ. Montpellier, Doc. Trav, Cent. Geolog. Geophys., 5.

Briqueu, L., Bougault, H., and Joron, J.L., 1984. Quantification of Nb, Ta, Ti and $\mathrm{V}$ anomalies in magmas associated with subduction zones: petrogenetic implications. Earth Planet. Sci. Lett., 68:297-308.

\footnotetext{
- Abbreviations for names of organizations and publications in ODP reference lists follow the style given in Chemical Abstracts Service Source Index (published by American Chemical Society).
} 
Briqueu, L., and Lancelot, J.R., 1982. Sr isotopes and K, Rb, Sr balance in sediments and igneous rocks from the subducted plate of the Vanuatu New Hebrides active margin. Geochim. Cosmochim. Acta, 47:191-207.

Chen, C.H., Shieh, Y.N., Lee, T., Chen, C.H., and Mertzman, S.A., 1990. $\mathrm{Nd}-\mathrm{Sr}-\mathrm{O}$ isotopic evidence of source contamination and an unusual mantle component under Luzon arc. Geochim. Cosmochim. Acta, 54:2473-2483.

Chung, W.Y, and Kanamori, H., 1978. A mechanical model for plate deformation associated with aseismic ridge subduction in the New Hebrides arc. Tectonophysics, 50:29-40.

Collot, J.-Y., Daniel, J., and Burne, R.V., 1985. Recent tectonics associated with the subduction/collision of the d'Entrecasteaux Zone in the Central New Hebrides. Tectonophysics, 112:325-356.

Collot, J.-Y., Greene, H.G., Stokking, L.B., et al., 1992.Proc. ODP, Init. Repts., 134: College Station, TX (Ocean Drilling Program).

Coulon, C., Maillet, P., and Maury, R.C., 1979. Contribution à l'étude du volcanisme de l'arc des Nouvelles-Hebrides: donnees petrologiques sur les laves de l'íle d'Efate. Bull. Soc. Geol. Fr., 21:619-629.

De Paolo, D.J., and Johnson, R.W., 1979. Magma genesis in the New Britain island arc: constraints from $\mathrm{Nd}$ and $\mathrm{Sr}$ isotopes and trace element patterns. Contrib. Mineral. Petrol., 70:367-379.

Dupré, B., and Allègre, C.J., 1983. Pb-Sr isotope variation in Indian Ocean basalts and mixing phenomena. Nature, 303:142-146.

Dupuy, C., Dostal, J., Marcelot, G., Bougault, H., Joron, J.L., and Treuil, M., 1982. Geochemistry of basalts from central and southern New Hebrides arc: implication for their source rock composition. Earth Planet. Sci. Lett., 60:207-225.

Eggins, S.M., 1989. The origin of primitive ocean island and island arc basalts [Ph.D. thesis]. Univ. of Tasmania, Hobart, Tasmania, Australia.

1993. Origin and differentiation of picritic arc lavas from Aoba (Ambae), Vanuatu. Contrib. Mineral. Petrol., 114:79-100.

Falvey, D.A., 1975. Arc reversals, and a tectonic model for the North Fiji Basin. Australas. Soc. Explor. Geophys. Bull., 6:47-49.

Falvey, D.A., and Greene, H.G., 1988. Origin and evolution of the sedimentary basins of the New Hebrides Arc. In Greene, H.G., and Wong, F.L. (Eds.), Geology and Offshore Resources of Pacific Island Arcs-Vanuatu Region. Circum-Pac. Counc. Energy Miner. Resour., Earth Sci. Ser., 8:413-442.

Girod, M., Maury, R., and Barsdell, M., 1979. Coexistence de basaltes sursatures et sous-satures en silice aux Nouvelles Hebrides. Problem de leur relation genetique. C.R. Acad. Sci. Ser. 2, 288:1355-1358.

Gorton, M.P., 1974. The geochemistry and geochronology of the New Hebrides [Ph.D. dissert.]. Australian National Univ., Canberra.

, 1977. The geochemistry and origin of Quaternary volcanism in the New Hebrides. Geochim. Cosmochim. Acta, 41:1257-1270.

Goula, X., and Pascal, G., 1979. Structure of the upper mantle in the convex side of the New Hebrides arc. Geophys. J.R. Astron. Soc., 58:145-167.

Hamelin, B., and Allègre, C.-J., 1985. Large-scale regional units in the depleted upper mantle revealed by an isotope study of the South-West Indian Ridge. Nature, 315:196-199.

Hart, S.R., 1984. A large-scale isotope anomaly in the Southern Hemisphere mantle. Nature, 309:753-757.

Hochstaedter, A.G., Gill, J.B., and Morris, J.D., 1990. Volcanism in the Sumisu Rift, II. Subduction and non-subduction related components. Earth Planet. Sci. Lett., 100:195-209.

Javoy, M., Briqueu, L., Lancelot, J.R., and Tatsumoto, M., 1986. Oxygen, strontium and neodynium investigations of Vanuatu intra-oceanic arc: structural control of magmatism. Abstr. I.C.O.G., Cambridge, 177.

Johnson, D.P., Belford, D.J., Carter, A.N., and Crawford, A.J., 1988. Petrology and age of dredged samples collected in the Central Basin, Vanuatu. In Greene, H.G., and Wong, F.L. (Eds.), Geology and offshore resources of Pacific island arcs, Vanuatu region. Circum-Pac. Counc. Energy Miner. Resour., Earth Sci. Ser., 8:141-161.

Loock, G., McDonough, W.F., Goldstein. S.L., and Hofmann, A.W., 1991. Mantle source compositions of Lau Basin basalts: evidence for presence of the Indian ocean mantle domain in the SW Pacific. EUG VI, Terra Abstr., 3:45.
Louat, R., Hamburger, M., and Monzier, M., 1988. Shallow and intermediatedepth seismicity in the New Hebrides Arc: constraints on the subduction process. In Greene, H.G., and Wong, F.L. (Eds.), Geology and Offshore Resources of Pacific Island Arcs-Vanuatu Region. Circum-Pac. Counc. Energy Miner. Resour., Earth Sci. Ser., 8:329-356.

Manhès, G., Minster, J.-F., and Allègre, C.-J., 1978. Comparative uraniumthorium-lead and rubidium-strontium study of the Saint Severin amphoterite: consequences for early solar system chronology. Earth Planet. Sci. Lett., 39:14-24.

Marcelot, G., Dupuy, C., Girod, M., and Maury, R.C., 1983. Petrology of Futuna Island associated with the initial stages of back arc. Chem. Geol., 38:23-38.

Marcelot, G., Maury, R.C., and Lefevvre, C., 1983. Mineralogy of Erromango lavas (New Hebrides): evidence of an early stage of fractionation in island arc basalts. Lithos, 16:135-151.

Mukasa, S.B., McCabe, R., and Gill, J.B., 1987. Pb-isotopic compositions of volcanic rocks in the West and East Philippine island arcs: presence of the Dupal isotopic anomaly. Earth Planet. Sci. Lett., 84:153-164.

Nakamura, N., 1974. Determination of REE, Ba, Fe, Mg, $\mathrm{Na}$, and $\mathrm{K}$ in carbonaceous and ordinary chondrites. Geochim. Cosmochim. Acta, 38:757-776.

Pascal, G., Isacks, B.L., Barazangi, M., and Dubois, J., 1978. Precise relocations of earthquakes, and seismotectonics of the New Hebrides island arc. J. Geophys. Res., 83:4957-4973.

Peate, D.W., Pearce, J.A., and Colley, H.C., 1991. Geochemical variations along the Vanuatu Island Arc, Southwestem Pacific. Terra Abstr., 3:46.

Prevot, R., Roecker, S.W., Isacks, B.L., and Chatelain, J.L., 1991. Mapping of low $\mathrm{P}$ wave velocity structures in the subducting plate of the central New Hebrides, Southwest Pacific. J. Geophys. Res., 96:19825-19842.

Richard, P., Shimizu, P., and Allegre, C.J., 1976. ${ }^{143} \mathrm{Nd} /{ }^{143} \mathrm{Nd}$, a natural tracer: an implication to oceanic basalt. Earth Planet. Sci. Lett., 31:269-278.

Richardson, S.H., Erlank, A.J., Duncan, A.R., and Reid, D.L., 1982. Correlated $\mathrm{Nd}, \mathrm{Sr}$ and $\mathrm{Pb}$ isotope variation in Walvis Ridge basalts and implications for the evolution of their mantle source. Earth Planet. Sci. Lett., 59:327342.

Roca, J.L., 1978. Contribution à l'étude petrologique et structurale des Nouvelles Hebrides [These 3 me cycle]. Univ. Montpellier II, Montpellier, France.

Stern, R.J., Morris, J., Bloomer, S.H., and Hawkins, J.W., 1991. The source of the subduction component in convergent margin magmas: trace element and radiogenic isotope evidence from Eocene boninites, Mariana forearc. Geochim. Cosmochim. Acta, 55:1467-1481.

Sun, S.-S., 1980. Lead isotopic study of young volcanic rocks from mid-ocean ridges, ocean islands and island arcs. Philos. Trans. R. Soc. London A, 297:409-445.

Von Drach, V., Marsh, B.D., and Wasserburg, G.J., 1986. Nd and Sr isotopes in the Aleutians: multi-component parenthood of island arc magmas. Contrib. Mineral. Petrol., 92:13-34.

White, W.M., and Dupré, B., 1986. Sediment subduction and magma genesis in the Lesser Antilles: isotopic and trace element constraints. J. Geophys. Res., 91:5927-5941.

White, W.M., and Patchett, J., 1984. Hf-Nd-Sr isotopes and incompatible element abundances in island arcs: implications for magma origins and crust-mantle evolution. Earth Planet. Sci. Lett., 67:167-185.

Zartman, R.E., and Doe, B.R., 1981. Plumbotectonics: the model. Tectonophysics, 75:135-162.

Zartman, R.E., and Haines, S.M., 1988. The plumbotectonic model for $\mathrm{Pb}$ isotopic systematics among major terrestrial reservoirs. A case for bidirectional transport. Geochim. Cosmochim. Acta, 52:1327-1339.

Date of initial receipt: 21 April 1992

Date of acceptance: 23 September 1993

Ms 134SR-019 